\title{
New archaeological data refering to Tărtăria tablets
}

\author{
Gheorghe Lazarovici' and Marco Merlini² \\ 7 "Eftimie Murgu" University in Resita, Romania \\ ghlazarovici@yahoo.com \\ 2 Prehistory Knowledge Project, Roma, Italy; Institute of Archaeomythology, Sebastopol, USA \\ marco.merlini@mclink.it
}

\begin{abstract}
We analyze and present new points of view regarding the 'Danube' script based on recent investigations of the old Tărtăria discoveries: archaeological context, anthropological expertise, absolute dating and the meaning of the renowned tablets.

IZVLEČEK - Analizirava in predstavljava nove poglede na 'Donavsko' pisavo, ki temelijio na sodobnih raziskavah starih odkritij iz Tărtărije: arheološki kontekst, antropološko strokovno mnenje, absolutne datacije in pomen slovečih plošč.
\end{abstract}

KEY WORDS - Tărtăria tablets; 'Danube script'; signs; symbols; priestess; ethno-religion

\section{DATA ABOUT THE SITE}

When the Tărtăria tablets were discovered many discussions and questions arose concerning their absolute chronology. At that time, the beginning of the Starčevo-Criş culture was dated to around $3400 \mathrm{BC}$ (Grbić 195.25, 27; Benac 1958. 41). Tărtăria-Groapa luncii is located near the CFR station Tărtăria, on a small promontory. Some time ago, below this pro-

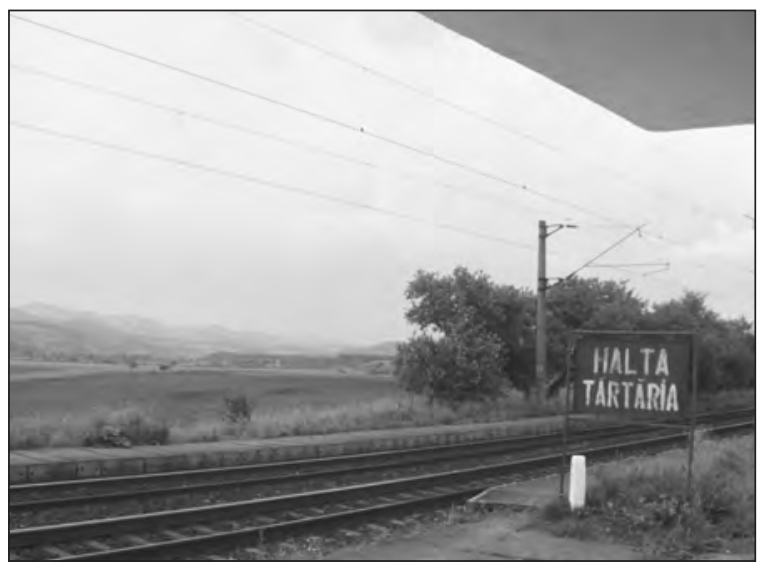

Fig. 1. Vinča settlement at Tărtăria. montory a branch of the Mureș River flowed; this branch received water from a small stream and other springs from the high terraces of the Mureş River (15 m high), which was greatly very much eroded flooding. Because of this we can now see a very abrupt and eroded bank in the area of trenches made by Kurt Horedt, Nicolae Vlassa or Iuliu Paul (1995),

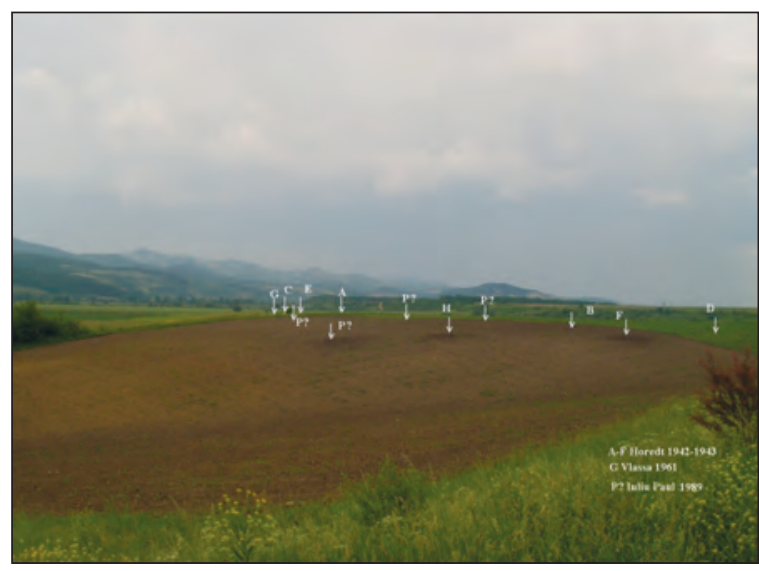

Fig. 2. Tărtăria: location of the excavations. 
which cover an area of about $200 \mathrm{~m}$ (Figs. 2 and 3).

Nicolae Vlassa believed that the tablets were related to proto-Sumerian writing, and that they offer the chance of making a cultural and chronological synchronisation of Europe and the Near East (Vlassa 1962; 1964; 1965). His opinion on this subject has been confirmed by Milojčic (1965) and Sumer expert Adam Falkenstein (1965). This opinion was also sustained by Makkay $(1969 ; 1990)$, Hood (1967; 1968) and others.

Most other archaeologist, champions of the long chronology, have not agreed with this opinion, looking for different kind of 'vices', 'errors' or 'myths'. They adopt other hypotheses (see Merlini 2004; $2004 a$ ).

Some new projects looking to reveal the truth about Tărtăria are supported by Marco Merlini with his "Focus on Tărtăria" from the Prehistory Knowledge Project, or the Institute of Archaeo-mythology, which with the Serbian Academy of Science and Arts has initiated a very interesting debate focused on the Danube Script.

Such a subject raises great in some other countries, among them Germany (Schier 2002; Sinn 2002), Bulgaria (Karlovo 2002 online), Austria (Der Turmbau zu Babel 2003) and Serbia (Symposium Novi Sad 2004). Therefore, in our opinion, the Ljubljana symposium is a new stage in the definition and results obtained by recent research.

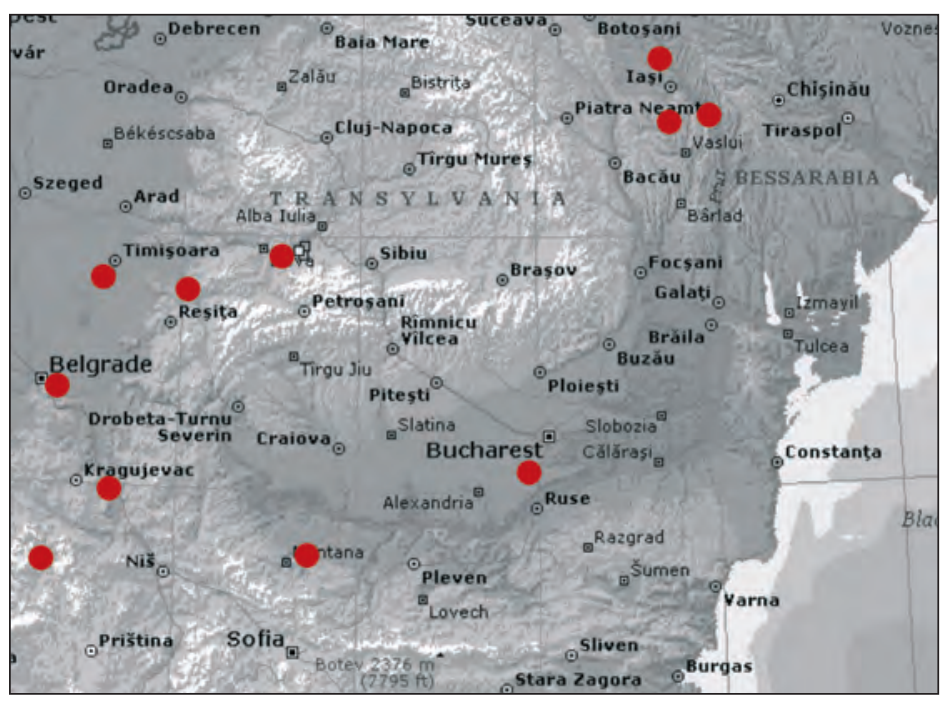

Fig. 4. Map with tablet distribution in SE Europe.
We now know that there are many tablets with signs in Europe (Fig. 4). There are also new data, information and even interpretations of such kind of discoveries (Gradešnica: Nikolov, Georgiev 1970; Nikolov 1986; Winn 1981; Winn 2003). Such pieces are known from the Early Neolithic in Romania and neighbouring regions (Perieni, Glãvãneşti), the Developed Neolithic (Tărtăria, Parţa), Late Neolithic (Turdaş, Orãştie, Sãlbãgel, Tangâru, Gradešnica, Rast, Suplevac) or Early Eneolithic (Isaiia, maybe Poduri too) (Fig. 4). The Tărtăria tablets are special because of their context.

\section{STRATIGRAPHICAL DATA AND THEIR INTERPRE- TATION}

These tablets were discovered in what Vlassa called a ritual pit (Vlassa 1962; 1964). He connected this pit with a pit house found nearby (Figs. 8 and 11). We must remember here that some pit houses have related areas nearby for household activities (Figs. $8-11)$. It is the same situation with the pit house and the ritual pit at the Tărtăria site. Both belong to the same level (h11) of excavation (Fig. 11).

The distance between the ritual pit and the pit house was 70 to $90 \mathrm{~cm}$, and they belong to the same archaeological complex. We have checked this, comparing the radiocarbon data obtained from the ritual pit and the pit house.

As we mentioned before, Vlassa (1962; 1964) and Sinclair Hood (1967; 1968), considered that these complexes contemporary. J. Makkay (1990.Fig. 1) put together on a larger plan Vlassa's sections and those made by K. Horedt to suggest their correlation and (Figs. 3 and 10).

Some archaeologists broke the ritual pit from its archaeological context and made free interpretations, as D. G. Zanotti did 
(Zanotti 1983, and our response, Lazarovici-Maxim 1991), in trying to solve the problem of chronology or typological association, as the anchors generally considered as belonging to the Cotofeni level and so on (see stratigraphy position Fig. 11).

Makkay wrongly located the ritual pit near the south profile of the trench. The correct position is in the northern border of this $\mathrm{G}$ trench's profile (Fig. 11). In the photo (Fig. 9) we can see the pit profile projection. We underline once more that the ritual pit was located in the northern profile of the cassette (Fig. 8).

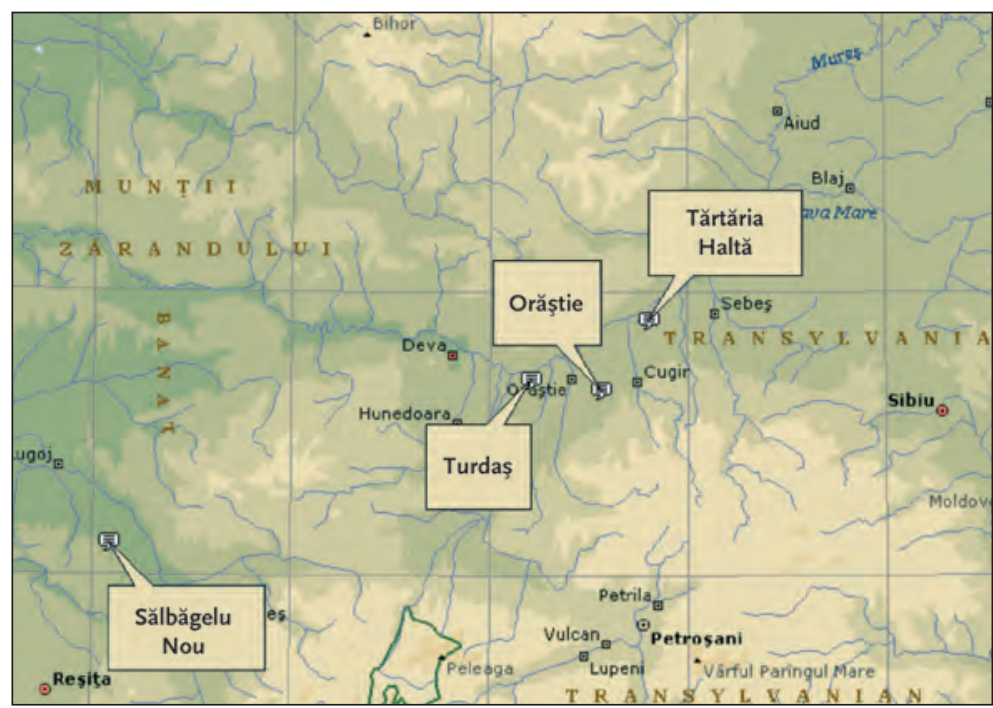

Fig. 5. Transylvanian sites with tablets.
Other scientists have furnished new, precise data (Masson 1984; Milisauskas 2002.236-237), while others have minimized the information and pictures published by Vlassa (Berciu 1967; Comşa 1982. 82-85). Therefore, we have to underline once more that is necessary to accept the fact that the pit house and the ritual pit belong to the same archaeological complex, they are contemporary, as the radio-carbon data prove. We do not intend to analyze here different speculations that have been made, because Merlini has done this already. The aim of this paper is to present new data and to reanalyse the objects and their conditions of discovery, to offer new arguments for their stratigraphy.

\section{THE SKELETON - ARCHAEOLOGICAL DATA}

The ritual pit contains various archaeological remains, as well as some parts of a human skeleton.

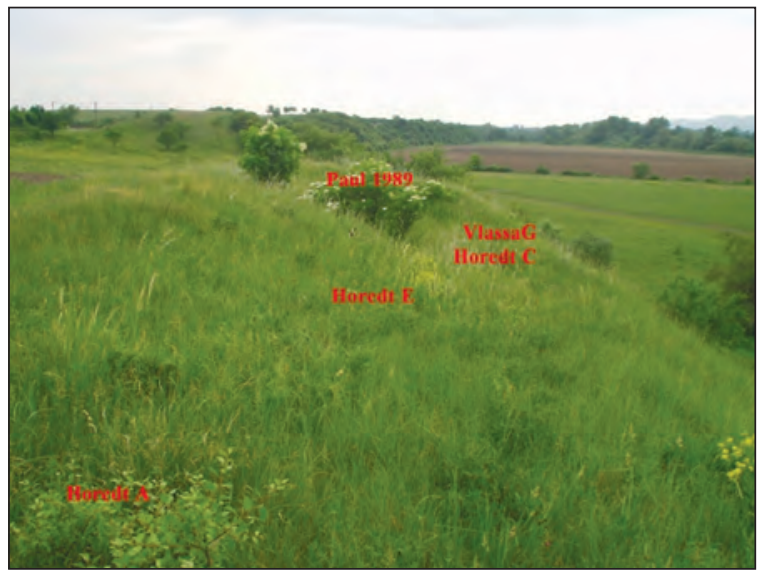

Fig. 6. Location of excavations by Horedt, Vlassa and Paul.
The shape and the extent of the ritual pit did not permit the deposition of an inhumation, and in fact the human bones were placed there after the flesh had been removed or an exhumation process.

Vlassa believed that the bones had been burnt. The bones had a charred appearance and traces of sponge or foam. Some parts of the skeleton, the skull and smaller bones, are missing. Only one of the bones among those recovered was burnt. Because at that time it was not possible to make an anthropological analysis, Vlassa did not wash the bones. We washed them and requested anthropological expertise. We believe that in fact the bones were bleached in the sun and therefore they have a whitish colour; a similar situation and rituals are known from the end of the Cotofeni culture until the Early Bronze Age (Lazarovici, Kalmar, Maxim 1987-1988; Lazarovici 1998; for defleshing/excarnation see Merlini 2004).

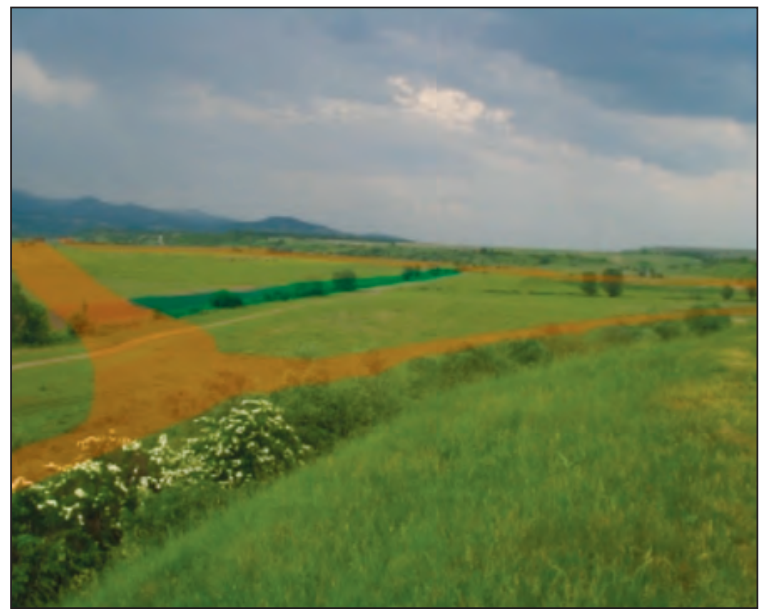

Fig. 7. Old River channel. 


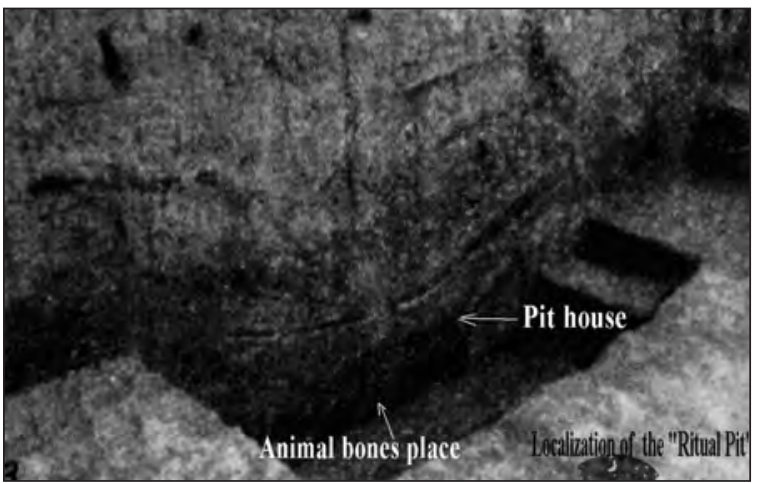

Fig. 8. The pit house; southern profile of G cassette made by Vlassa (photo N. Vlassa).

Our hypothesis was sustained by the forensic study made by Georgeta Miu, at the Center for Biological Research, of the Romanian Academy. Only one bone belonging to an animal, showed signs of burning, and this was mixed with the human ones, which had no traces of burning (Lazarovici, Miu 2004). The animal bone may have been be put together with the human upon interrment, perhaps in relation to mortuary or funerary rituals. Georgeta Miu has also observed that the skull and many small bones (such as those from the palms or feet) are missing. This might be the result of a natural process, such as when scavengers take these parts (see Lazarovici 2000). We cannot explain the absence of the skull bones. In almost cases of defleshing process, skull bones as well as teethes are preserved even the small bones of the face are disappearing. Therefore, we hypothesise that the absence of the skull might be related to a skull cult (our opinion and bibliography, LazaroviciMaxim 1995). But we have also to check the materials once again from the earlier excavations by Horedt and Vlassa to be sure that they were not mixed with other materials or overlooked when the profile was cleared (Fig. 11). This last hypothesis is supported by Vlassa's photos, which shows that the pit was partially cut (Fig. 9).

The radiocarbon date for the human skeleton from the ritual pit is level h11, Rome - 1631, $6310 \pm 65$

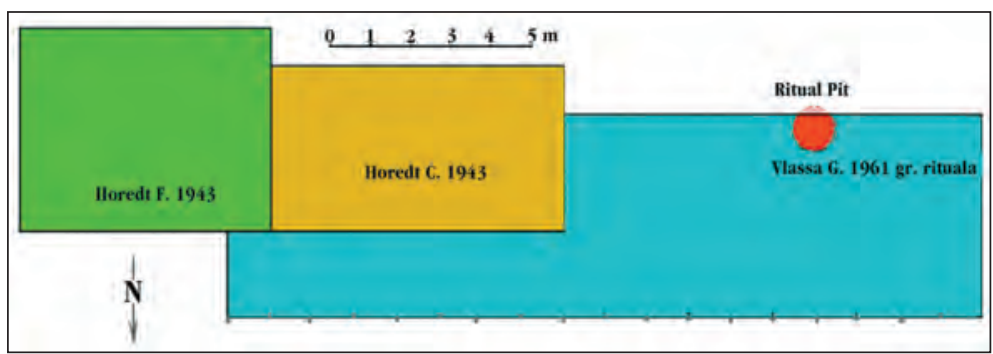

Fig. 10. The site of the ritual pit after Makkay and others is wrongly located on the southern profile.

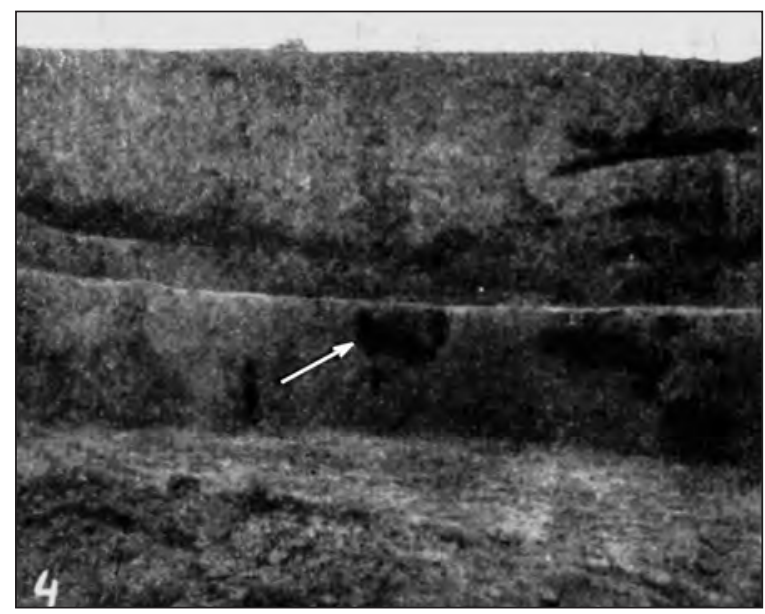

Fig. 9. Ritual pit, the northern profile of G cassette, projected in a photo profile by Vlassa.

yr BP $(1 \sigma, 5370-5140 \mathrm{Cal} B C)$; the radiocarbon date for the animal bones found at the bottom of the pit house is level h16+h17, Rome - 1655, 6210 $\pm 65 y r B P(1 \sigma, 5280-5060 C A L B C)$, and mixed cultural level, Rome - 1630, $6200 \pm 65$ BP. These results show that they were partly contemporaneous. We believe that in this case Tringam's observations (Tringham 1971), or Zanotti (1983) have no real basis.

\section{THE SKELETON - ANTHROPOLOGICAL DATA}

The whitish colour of the human bones might be related to long exposure during a defleshing/excarnation process. The forensic results were stated by Merlini (Merlini 2004a): "The skull and pelvis are missing (from the latter there are only some fragments); the sex and age determination of the subject has some limitations. Dr. Georgeta Miu, based on metric and morphological features of the long bones (entire or fragmentary) and others anthropological features, considers that the bones belong to a female of 50-55 years old. The age was estimated based on: reabsorption of spongy tissue, the appearance of the pubic area, and some particular pathological degenerative processes in some bones. The height is $147 \mathrm{~cm}$, indicative of a small woman. It was calculated on the basis of classic known methods (radius, cubitus and tibia length).

Our analysis and conclusions are based on the small height of the subject and on the gracile features of the bones. We recall that the skull 


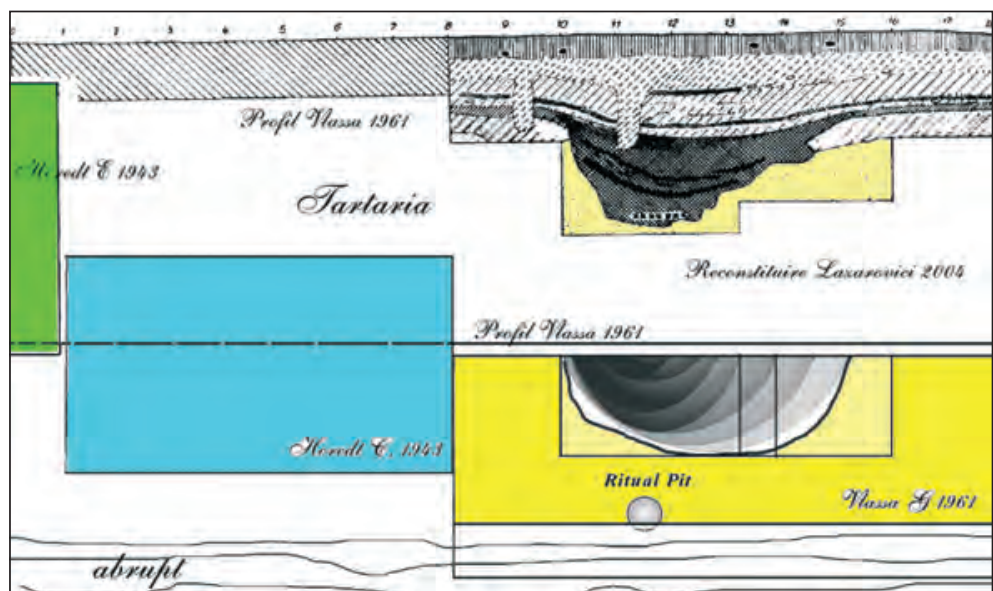

Fig. 11. Tărtăria, stratigraphy; location of the ritual pit $\Delta$; profile of cassette $G$ made by Vlassa, and different levels of excavation (Reconstruction, Lazarovici).

and facial bones are missing. Based on the available data we believe that all these features indicate a Mediterranean type.

The lower part of the articular surfaces of the pubis show a similar degenerative process. We do not

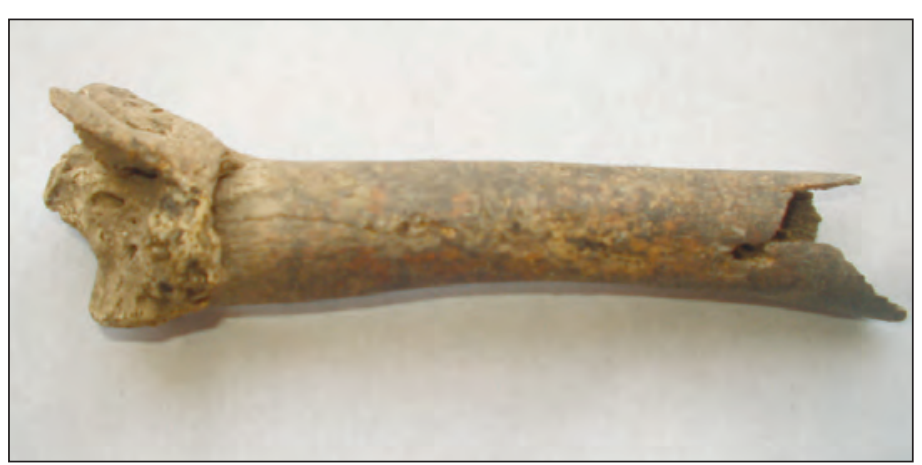

Fig. 12a. Distorted femur.

know the origin of these bone lesions, but they are associated with a quite high process of osteoporosis. All these degenerative processes may have produced great pain and it is probable that she experienced pain in the last 10-15 years of her life. But her death can be related to other reasons" (Lazarovici, Miu 2004; Merlini 2004a).

We would like to underline some aspects related to the first impression that the bones were burnt. This might be related to the spongy aspect of some of the bones, with holes and swellings. Miu observed these features and asked for a further opinion from Dinu Oneţ a radiologist and physician at the Neurosurgery Clinic in Cluj-Napoca, who suggested some explanation for these kinds of deformation.

Radiological expertise and clinical analogies indicate gummatous osteoperiostitis, tuberculosis or osteomelites. We also do not exclude an ancient strain of syphilis (Merlini 2004; Marcsik 1994; Baker and Armelagos 1988; Dennie 1962; Hershkovitz et al. 1995).

\section{OPINIONS ON THE MEANING OF THE CULT OBJECT FROM THE RI- TUAL PIT}

The modification of some information relating to the content of the ritual pit, of anthropological or geological data, lead us to present new data, information, and opinions about the meaning of the pieces discovered in the cult pit (close to or different from those of Vlassa), about their deposition and their state of preservation.

Taking into account the fact that the human bones belong to an old, ill woman with specific disabilities in walking (Merlini $2004 a$ ) we believe that two hypotheses must be considered: a) it is a "priestess" or a person with a similar function, not well enough defined; b) or a "shaman"/"sorcerer" (as Vlassa suggested, but in this case it is a woman) who inherited

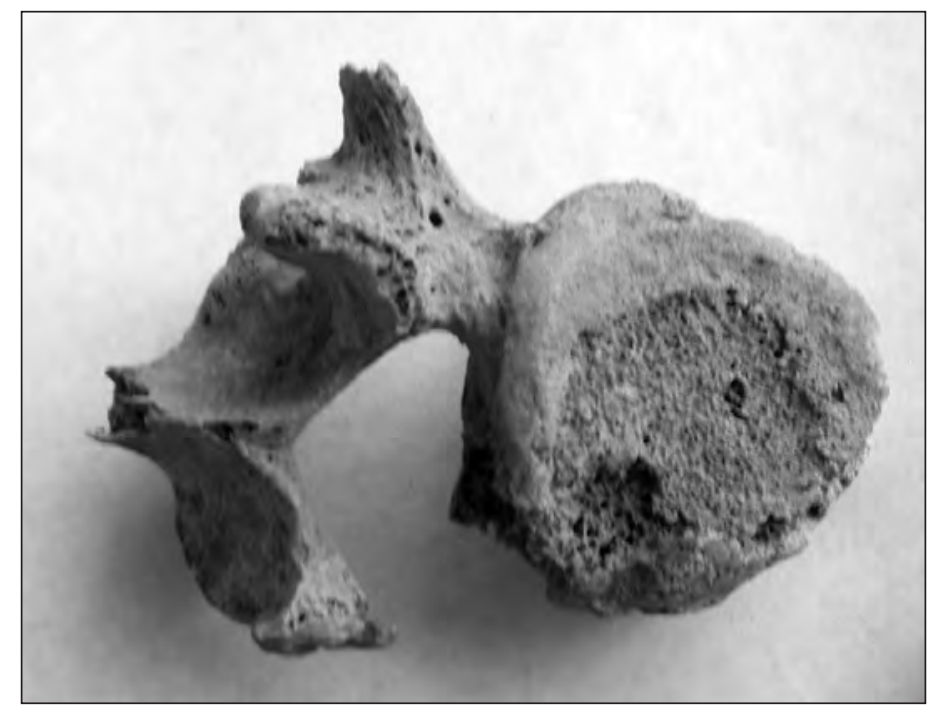

Fig. 12b. Distorted rib. 


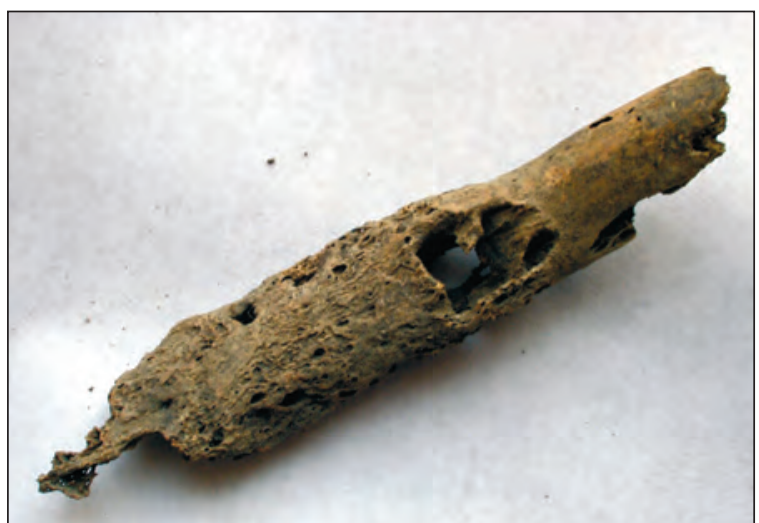

Fig. 13a. Rib with specific feature of gummatous osteoperiostitis.

the objects, together with some knowledge (in both cases this last assumption is probable). The pit contained many objects (Fig. 15), some broken, intentionally or not, others whole.

\section{Broken objects}

- Both anthropomorphic idols. In this case, the meaning is that there are not relations between this owner and divinity (Figs. 16a, 16b).

- Fragment of the "anchor". This might have been used for weaving (Fig. 16c).
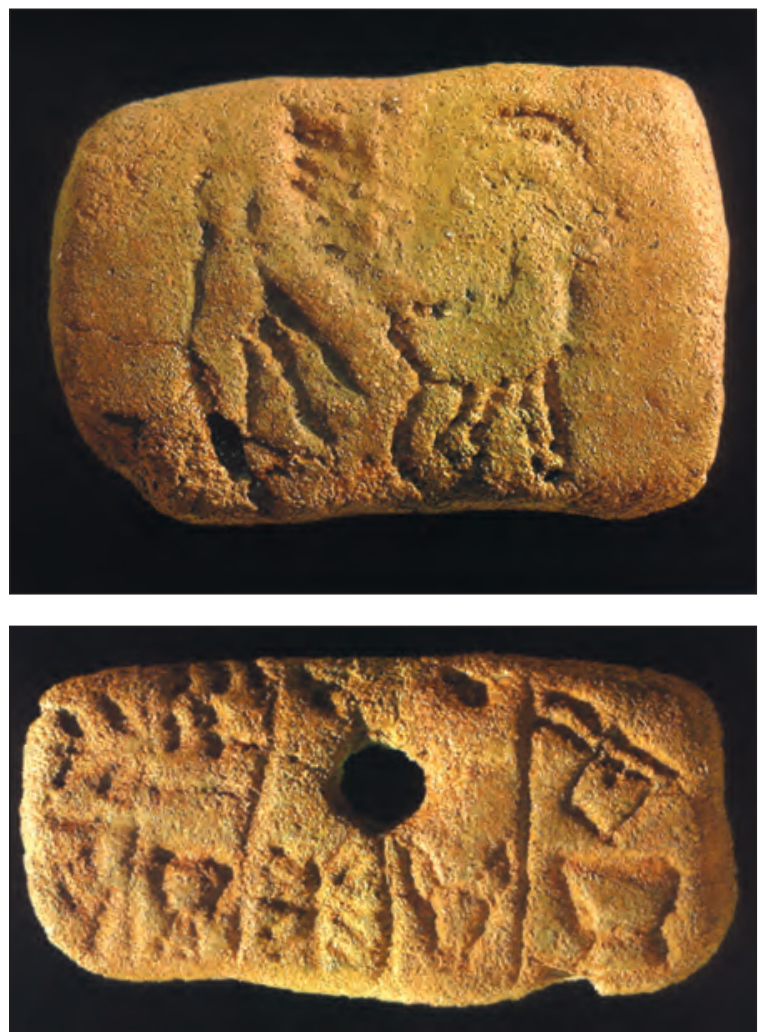

Fig. 14. Tărtăria tablets T1 and T2 up, T 3 down left $\Delta$; 4) pendant, tablet T3 cover the signs from T2, upper register.

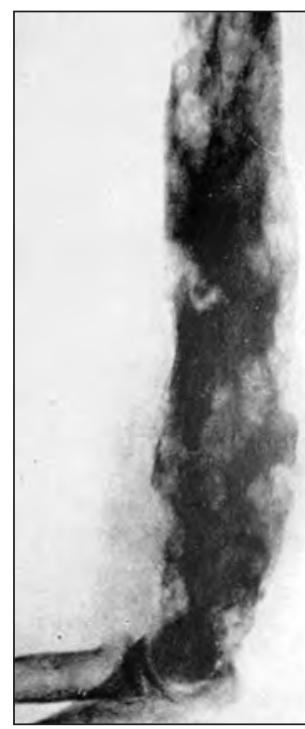

Fig. 13b. Gummatous osteoperiostitis, form of a humerus pseudo tumor (child 14 years old).

- Intentionally broken alabaster idol (Fig. 16d).

- Bracelet, made of a very perishable material, might have been broken intentionally during the defleshing process (Fig. 17a).

- Altar, with right part broken (Fig. 17b).

- Fragmented head of an anthropomorphic idol (Fig. 17c).

There are many rituals related with intentionally broken cult pieces which are then burnt.

\section{Whole objects}

Among the whole pieces we have to mention two idols of a phallic type. Perhaps their destruction was prohibited because they were objects directly related
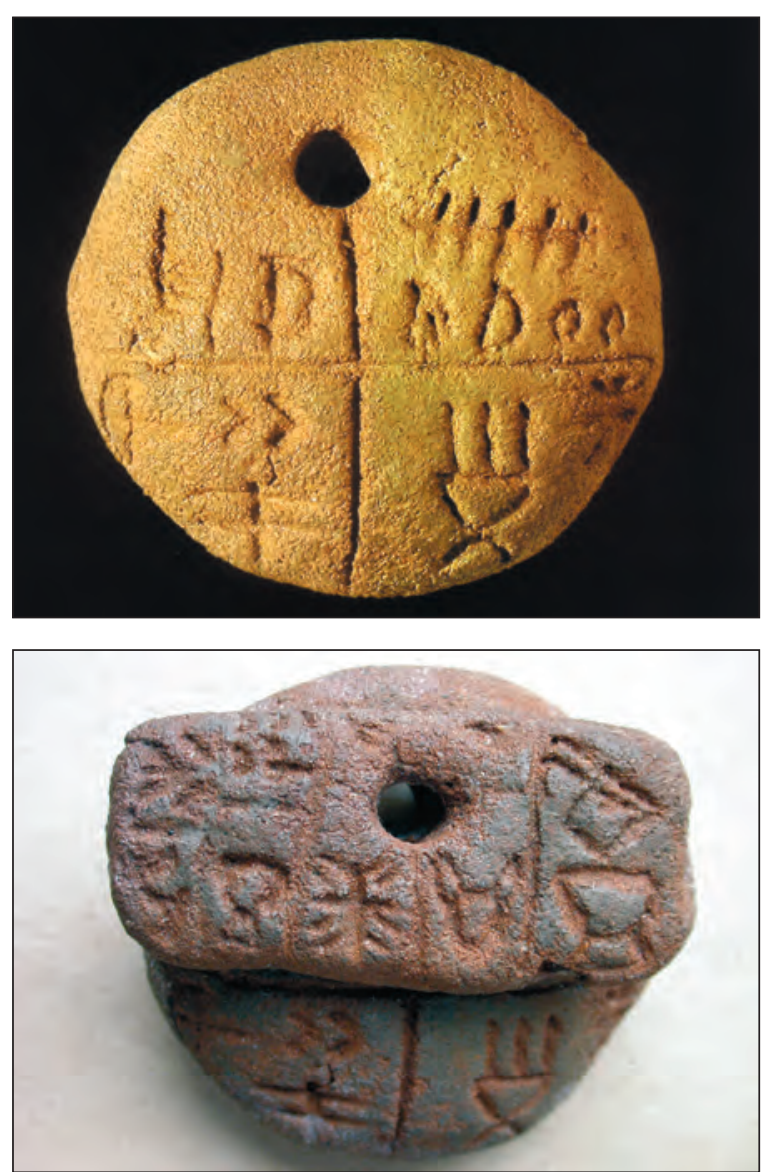
to fertility, fecundity, or ritual defloration. Their destruction might bring trouble to their makers.

\section{GEOLOGICAL DATA ABOUT THE TAB- LETS (FIGS. 14-15, 19-21) - THE MIX- TURE AND THE PASTE}

Professors Lucreţia Ghergari and Corina Ionescu made microscopic studies of the tablets at the Faculty of Geology, Geological Department of Cluj University and observed the following:

- All the pieces are made of the same type of material, which contains a very small quantity of clay and a large quantity of sand. This mixture is still a problem. The pieces have been treated with clorhidric acid to clean the surface. Because of the mixture of the material which contains a lot of calcium carbonates, many cracks appear during this process.

- On the surface of the pieces there seems to be a high concentration of calcium carbonate. To solve this problem it is necessary to obtain new samples; this is very difficult, since the pieces belong to the "treasure" of the national cultural heritage and there are special rules for preservation and investigation. - Signs were made by incision, repeat pressure or impression (especially the small signs: Figs. 19 and 21.3); the long incisions have irregular traces which deform the route of the lines (Figs. 19 and 21.2).

\section{About the "faking" of the tablet}

In the archaeological literature, on different notes, but also in different discussions, some archaeologists say that the tablets are fakes and that they were fired. From our discussions with Vlassa, we conclude otherwise. After the three pieces were cleaned in the clorhidric acid, many small cracks appeared, so that the pieces had to be conserved. For this a special fluid (nitro-varnish and dilutant) was used; for better, deeper penetration after the pieces were

We noted that to clean the calcareous deposit from the surface of the pieces they were placed in a clorhidric acid bath. This greatly affected the calcareous inclusions and the binding of the material the pieces were made of (based on calcar). To reanalyze these thin section analysis is needed.

There was a grass fibre (Fig. 20) on the superior part of one of the pieces. This fibre was covered with a clay stratum and a carbonate scab.
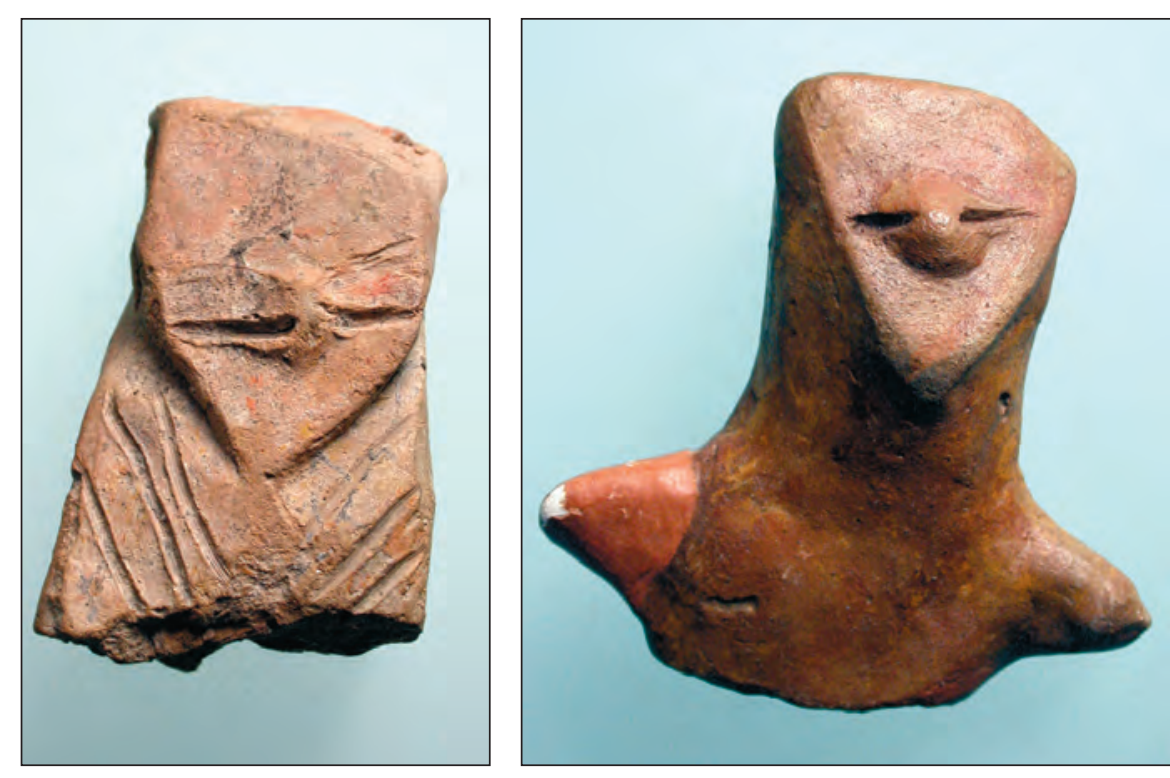

Fig. 16a and 16b. Intentionally broken female idol. 
treated with this mixture, they were placed in a drying chamber at a low temperature. Therefore it was this which caused the fragility of the pieces the cleaning with clorhidric acid affected the carbonates binding the tablets. Other pieces, made of similar material, if not washed in clorhidric acid, do not suffer such a problem. A coarse/rude material can be used to make many cultic objects. This custom is a religious condition, not related to technology or the skill of the maker.

The best examples are the Isaiia or Poduri cultic treasures of Precu-

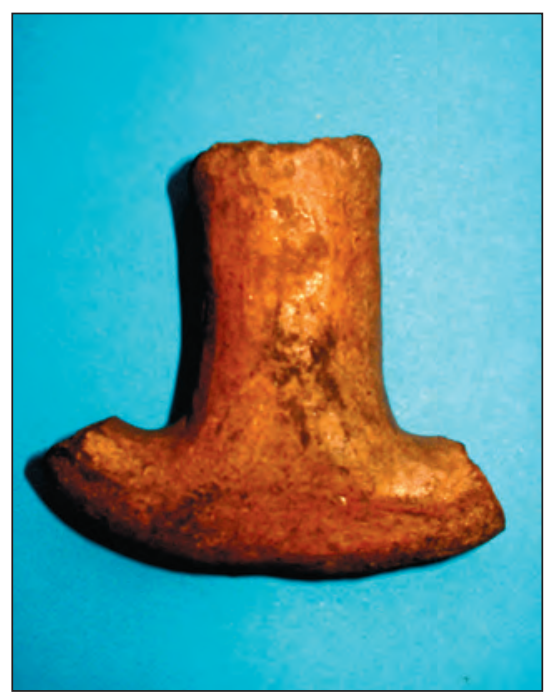

Fig. 16c. 'Anchor'.

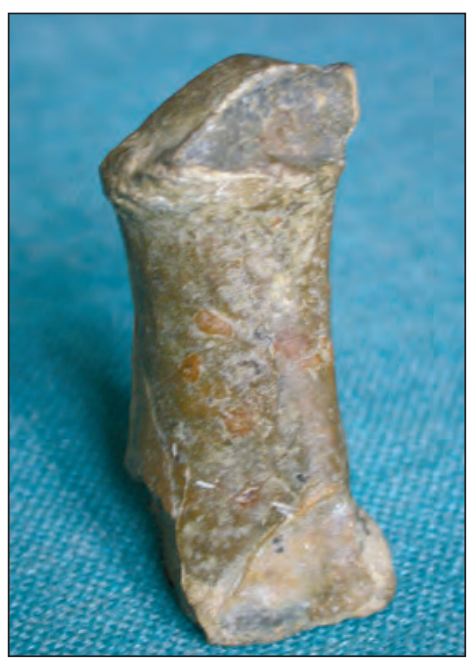

Fig. 16d. Intentionally broken alabaster idol. cuteni culture, kept in pots of rough clay, withough a careful finish, in a civilization renamed for the quality of its ceramics (Ursulescu 2004.327, Fig. 4; Ursulescu et al. 1999; 2001; 2002).

Such situations have been observed too for other clay artefacts (altars, pintaderas, cult pots etc.).

\section{Opinions regarding the meaning of the tablets}

Vlassa considered that writing system related to proto-Sumerian civilization; adherents of the short chronology have seen the tablets as a chronological landmark through a connection with Uruk-Warka-Djemdet Nasâr cultures (see Vlassa 1970; Milojčić 1965; Falkenstein 1965; Makkay 1990; Hood 1967). Op-

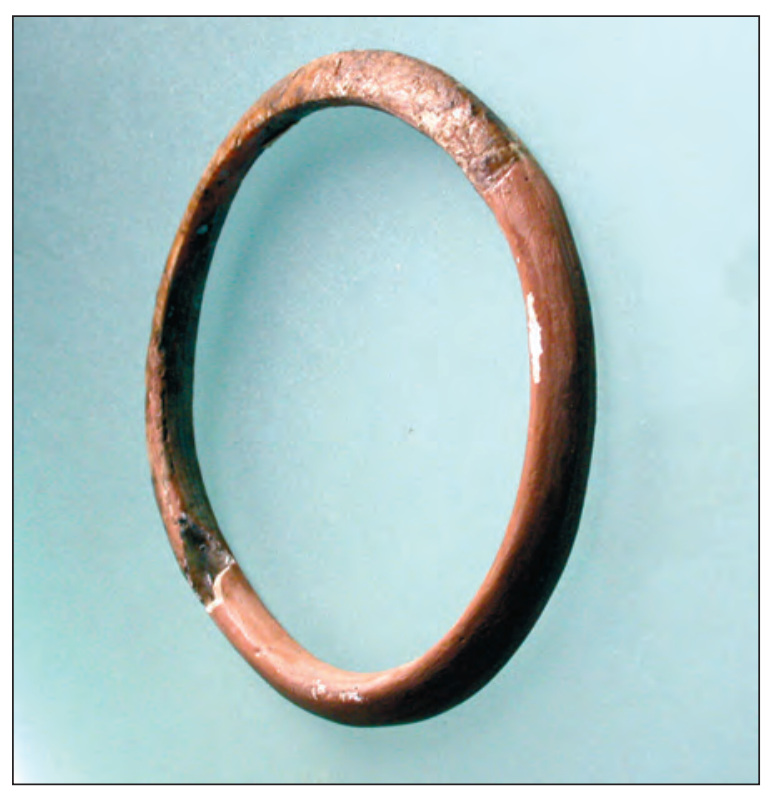

Fig. 17a. Bracelet. posing opinions have been expressed by the long chronology camp, based on the $14 \mathrm{C}$ data presented and analyzed by M. Merlini (2004; 2004a).

We consider that the cultic inventory belonged to a 'priestess'. We believe that this inventory was related to ritual and specific procedures, as rites of passage or other rites. Writing in this case has a cultic character; it is sacred writing expressed through ideograms, but also through signs and symbols; some might represent words or estates (Lazarovici 2002; 2004a; 2004b, 2004c).

The tablets we refer to here are not the first. We know others from the Paleolithic period at Mitoc, Cosăuţi (Borziac 1991.67, Fig. 2/3; Merlini 2004), from the Early Neolithic at Glăvăneşti and Perieni, the Late Neolithic at Turdaş, Orăştie, Homojdia, Parța, Svetozarevo, and Gradešnica etc. In all these cases, the signs have a cultic purpose. We have to mention another 3000 signs, variants and combinations

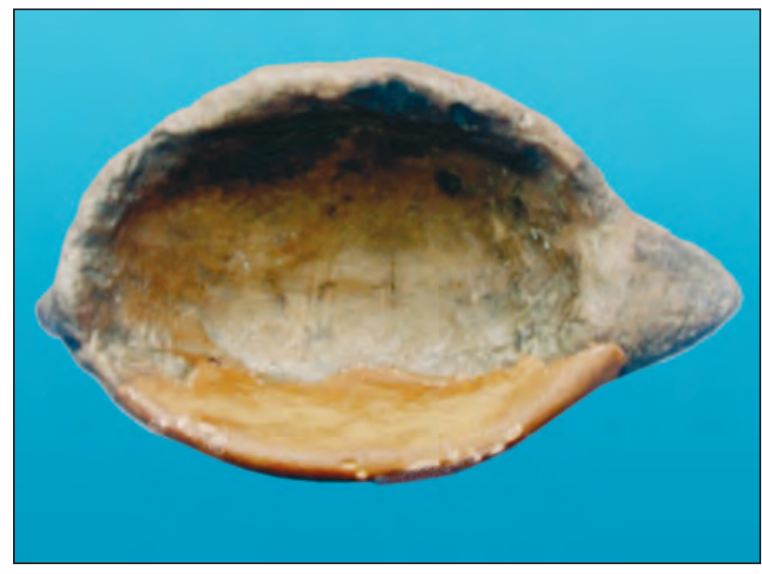

Fig. 17b. 'Zoomorphic altar'. 


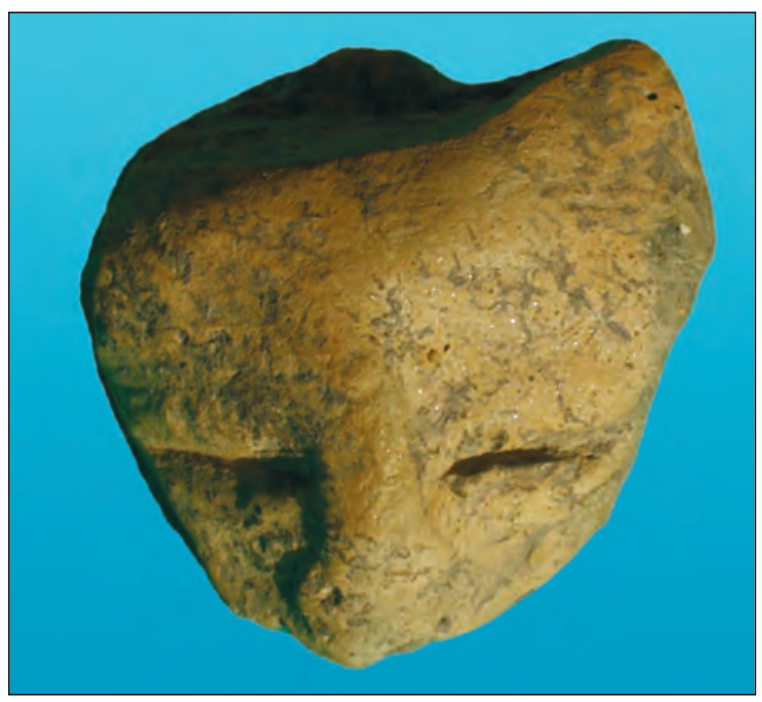

Fig. 17c. Head from a cylindrical idol.

house investigated by Vlassa (Fig. 8). Calibration with $1 \sigma$ indicates $5190-5060$ calBC, with $43.1 \%$ probability (Fig. 23). The third sample was selected from the material of the first levels, which contains bones from the cleaning of the profile and those thrown away during by the excavation by Horedt.

\section{CONCLUSIONS}

- The ritual pit is contemporary with the pit house: radiocarbon data sustain this conclusion. It is also possible that its function is related to the same pit house. We suppose that this woman was living in the pit house and the ritual pit was for storing religious paraphernalia. Her bones, after exhumation were returned to the place where she was living.

found on idols, pintaderas, altars or cult pots (Lazarovici 2003; 2004a; 2004b).

\section{Absolute chronology (Figs. 22 and 23)}

Radiocarbon data have been obtained using samples (animal bones) from the deepest levels of the Tărtăria pit house, and female bones from the ritual pit. We collected samples from all levels of the site, but there were funds to analyze only three samples.

Sample R 1631 was taken from one of the arms of the skeleton (very rich in bone material). The result of the sample is $6310 \pm 65$ BP. Calibration with $1 \sigma$ indicates $5370-$ 5140 calBC.

The second sample was obtained from animal bones from the deepest level of the pit

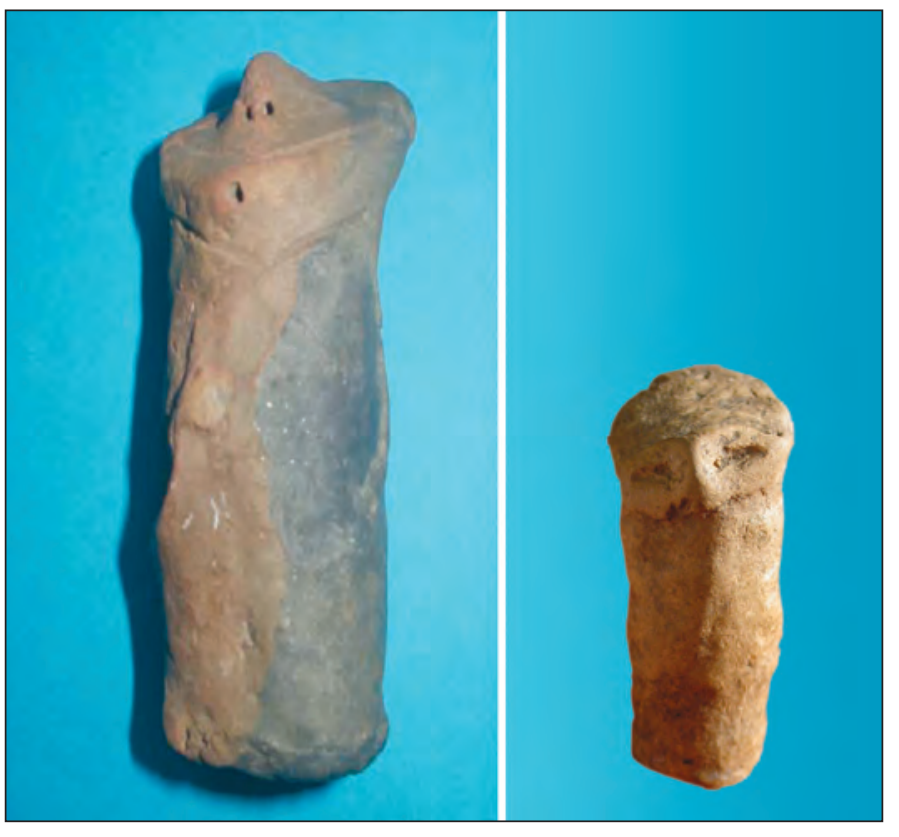

Figs. 18a and 18b. The large and the small ceramic 'phalli'.

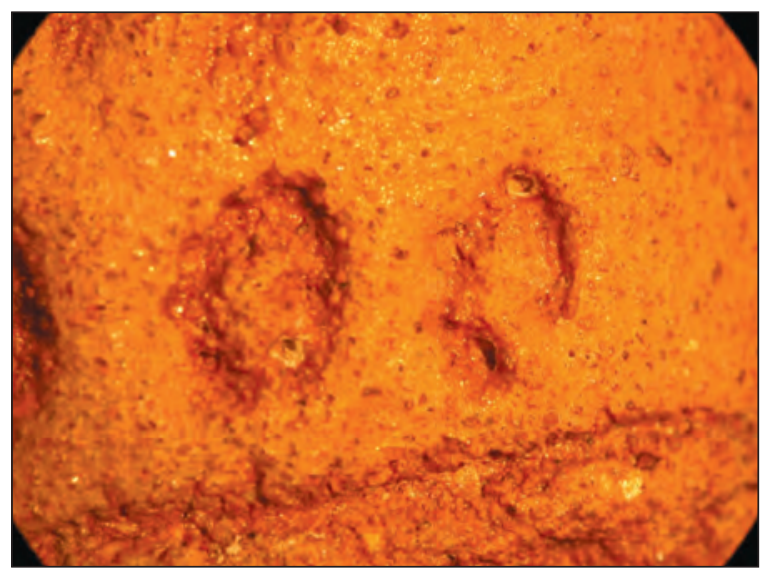

Fig. 19. The round tablet 2. Detail l - some calcareous areas destroyed by acid treatment.

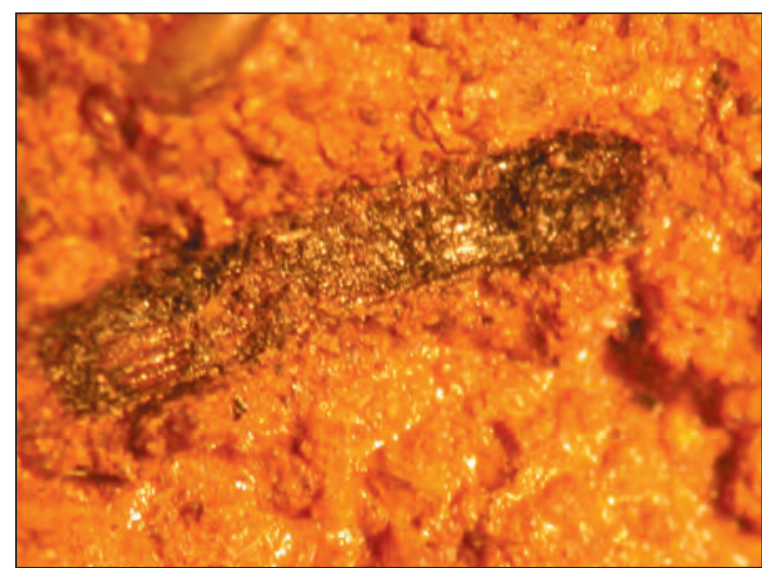

Fig. 20. Organic mixture from modeling, final stage. 


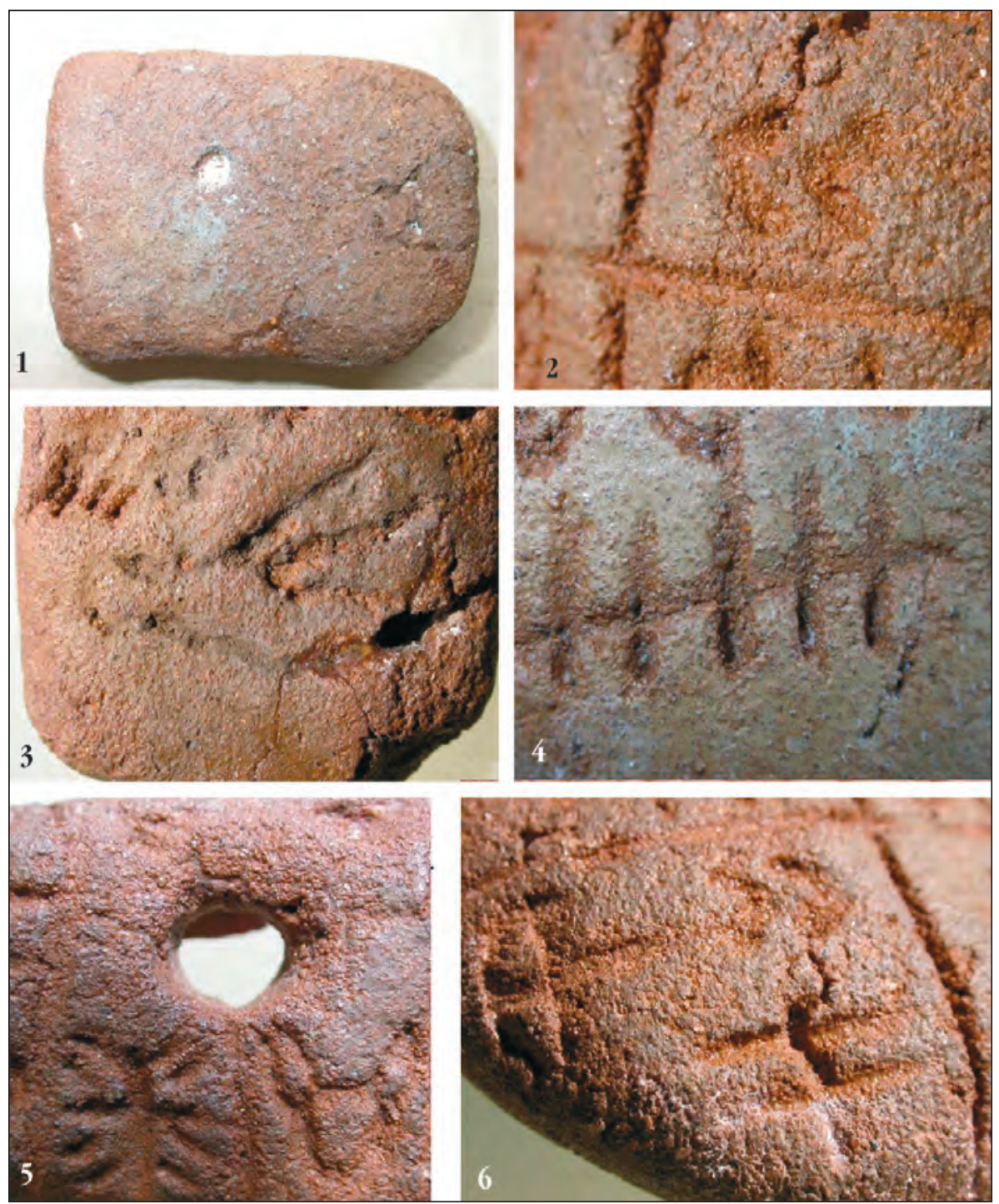

Fig. 21a. 1, 3 -tablet 1; 2, 4-tablet 2; 5, 6 - tablet 3. with signs and have a religious meaning.

- Excarnage supposes a period of between some months to $6 / 7$ years. It is possible that in this period the house was abandoned. To this period we can relate the first filling levels. Perhaps the cult inventory of the priestess was destroyed after her death, as a ritual, when she was not in direct relation with the divinity.

- The Tărtăria complex, based on ${ }^{14} \mathrm{C} \mathrm{da}$ ta and stratigraphy, belong to the early Vinča period, between the Starčevo-Criş IVA discoveries (contemporary with Vinča A2), and those from the Cârcea, Banat culture (Mantu 1998a; 1998b; 2000; 2002; 2003) or those early Vinča from Liubcova, Orăştie, Turdas I and Uivar (Man-
Such a hypothesis is supported by two cult discoveries from Poduri and Isaiia which contained 42 pieces. We presume the existence of some special houses belonging to the 'priestess', 'older' or 'wiser' women, often related to the number 7 .

- The tablets and other objects from the ritual pit belong to the cult inventory of a priestess. The same is true of the pit house. The objects belong to different cults relating to fertility and fecundity (the Great Goddess and her hypostasis: fertile mother, clever mother). The tablets and their signs represent another problem: they are related to an initiation process; they represent symbolic objects

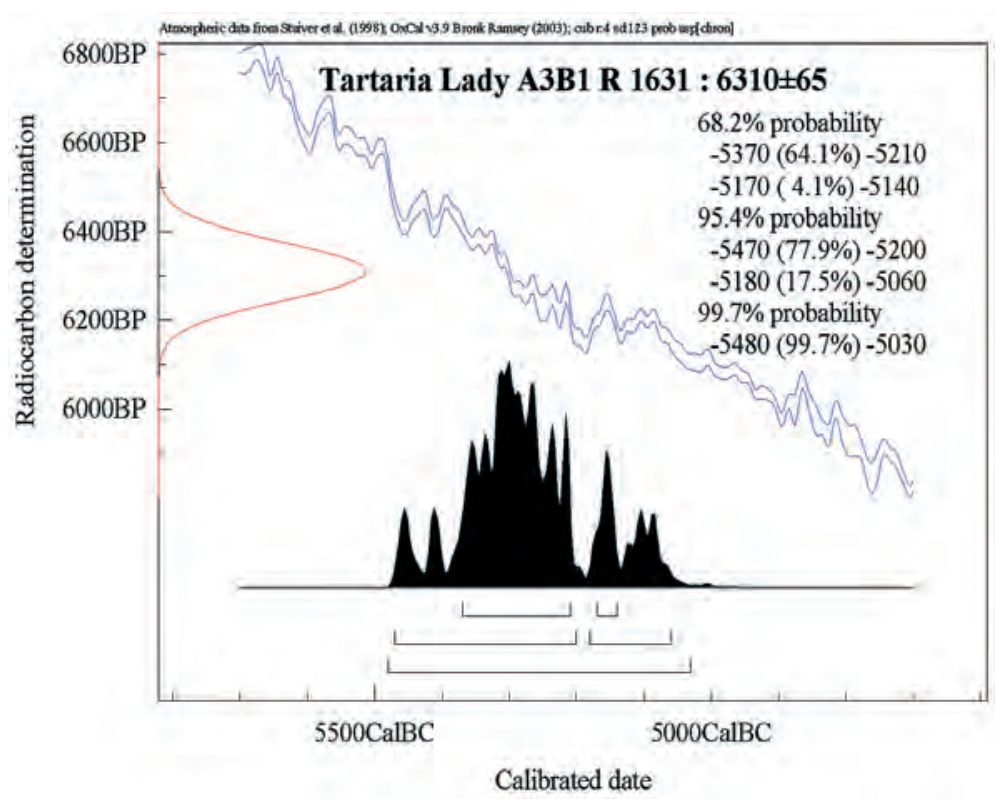

Fig. 22. Tartaria lady - absolute chronology. 


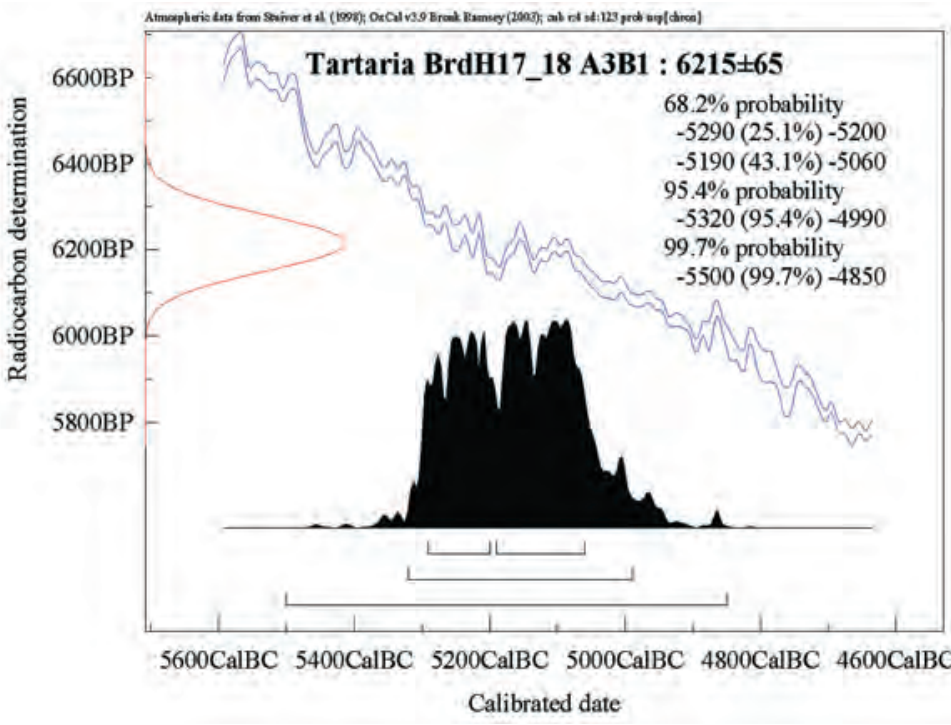

Fig. 23. Diagram of data obtain from the bones of the pit house base.

tu 1995; 1998a; 1998b; 2000; László 1997; Schier \& Draşovean 2004).

- On the Tărtăria tablets we find the greatest number of sign combinations. Before and after the Tărtăria discoveries some have spoken of an ancient European script (Masson 1984), with southern or Near Eastern connections. Such ideas have been assumed and developed by Vlassa (Vlassa 1971.161-197; 1976; PhD 1977 m.s). Tablets discovered in Romania and other places have been summarized and analysed by various archaeologists, such as Winn (1981), Makkay (1990), Ursulescu (1998), Lazarovici (2001; 2002; 2003; 2004) and Merlini (2004). Today we have a larger number of such pieces, and scientists speak of a 'Danube script' (Haarmann 1996; 1997; 1998; 2002; 2004; 2004 on-line; Symposium Novi Sad 2004; Merlini 2004a; Lazarovici 2004a; 2004b; Winn 2004; Winn on-line). This involves the 'Vinča script' (Winn 1981; 2004; Starović 2004), "the Turdass script" (Makkay 1969; 1990 and bibl.), or the 'Gradešnica script' (Nikolov, Georgiev 1970; Nikolov 1986). We believe that in fact this is merely the beginnings of a script, with a cultic, initiatory character; therefore we believe that many meanings were esoteric, being revealed only partially on the occasion of specific initiations.

The problem of the signs on the tablets and their meaning is a very complex one. Merlini has observed that when we overlap the perforated tablets (T2 and T3, Fig. 14), perhaps a pendant, a part of the text from tablet 2 was covered by tablet 3, possibly an esoteric text. We have analysed some groups of signs and their meaning, but the formation of the database is still in progress; our method of interpretation is still developing, and thus far now we have analysed only some subjects as light fire, sexuality, consecrated liquid (Lazarovici 2000; 2000a).

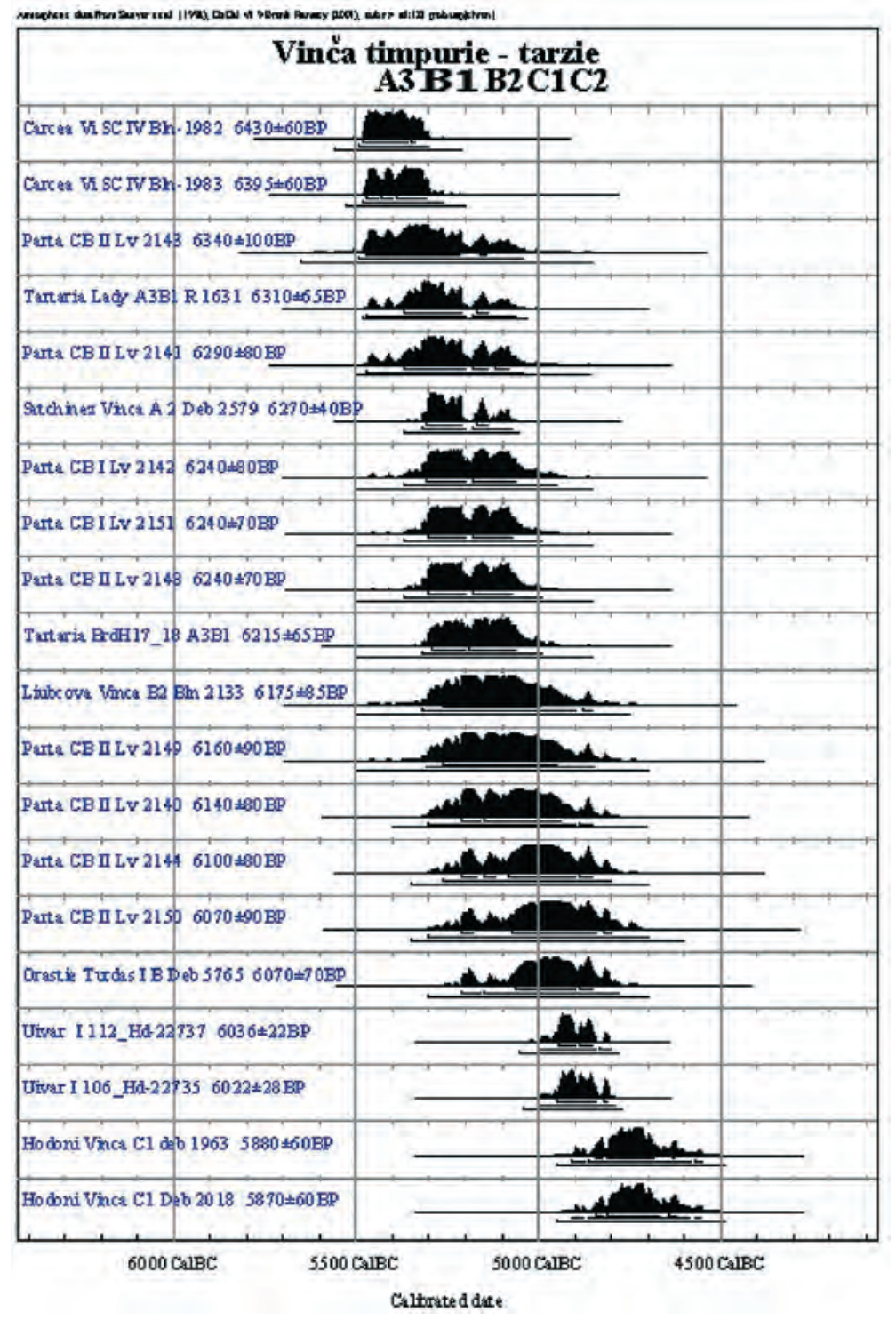

Fig. 24. Absolute chronology of Early Vinča. 


\section{REFERENCES}

ANTHROPOLOGY 2002. Last Lecture: Paleopathology, Spring 2002. on-line http://www.anthro.ucdavis.edu/ courses/ s02/ant156/Lecture\%2014.htm

ARMELAGOS G. J., MILLS J. 0. 1993. Palaeopathology as Science: the Contribution of Egyptology. In Davies W. V. and Walker R. (eds.), Biological Anthropology and the Study of Ancient Egypt.

BAKER B., ARMELAGOS G. J. 1988. The Origin and Antiquity of Syphilis. Current Anthropology 29 (5): 703-738.

BENAC A. 1958. Crvena Stijena. Glasnik Zemaljskog muzeja u Sarajevu (n. s.) XIII: (41).

BERCIU D. 1967. Romania. Thames and Hudson. London.

BORZIAC I. 1991. Quelques données prealables sur l'habitat tardipaléolithique pluristratifié de Coseoutsy sur le Dniester Moyen. In V. Chirica, D. Monah (eds.), Le paléolothique et le néolithique de la Roumanie en contexte Européen, Iaşi: 56-71.

BUCHVAROV K. 2003. Neolitni pogrebalni obredi. Intramuralni grobove ot Bulgarskite zemi v konteksta na Jugoiztochna Evropa i Anatolia (Neolithic Mortuary Practices. Intramural burials in Bulgaria in their southeast European and Anatolian context). Bard, Sofia.

CARTER C. (ed.) 1998. The Chora of Metaponto: The Necropoleis (2 volumes) University of Texas Press. Austin.

COMȘA E. 1982. Neoliticul din România: 82-85.

DENNIE C. 1962. A History of Syphilis. Thomas. Springfield.

FALKENSTEIN A. 1965. Zu den Tafeln aus Tartaria. Germania 43: 269-273.

GARDNER L. 2000. The Realm of the King Lords. MediaQuest, London (Italian version Del Regno Dei Signori Degli Anelli, 2000).

GIMBUTAS M. 1989. The Language of the Goddess. San Francisco.

1991. The Civilization of the Goddess. San Francisco.
GRBIĆ M. 1955. Vorklassische Keramik des Mittleren Balkans. Starinar V-VI: 25, 27.

HAARMANN H. 1995. Early Civilization and Literacy in Europe. An Inquiry into Cultural Continuity in the Mediterranean World. Berlin, New York.

1996. Early Civilization and Literarcy in Europe. An Inquiry into Cultural Continuity in the Mediterranean Worold. Ed. Mouton de Gryuter. Berlin - New York.

1997. The development of sign conceptions in the evolution of human cultures. In Posner et al. (eds.), A Handbook on the Sign - Theoretic Foundations of Nature and Culture, Berlin.

1998. On the Nature of Old European Civilization and its Script. In Studia Indogermanica Lodziensia, vol II.

2002. Geschichte der schrift. Monaco.

2003. Sign Inventory of the Old European Writing. Prehistory Knowledge project. on-line http:// www.prehistory.it/mappadeisegnili.htm

HERSHKOVITZ B. M. ROTHSCHILD, S. WISH-BARATZ and C. ROTHSCHILD 1995. Natural variation and differential diagnosis of skeletal changes in Bejel. L'Origine de la Syphilis en Europe avant ou après 1493? In 0. Detour, G. Palfi, J. Berato, J-P Brun (eds.), Center Archeologique du Var: 81-87.

HOOD M. S. F. 1967. The Tărtăria Tablets. Antiquity 41: 99-102.

1968. The Tărtăria Tablets. Scientific American, vol. $218, n .5$.

LÁSZLÓ A. 1979. Datarea prin radiocarbon în arheologie. Bucharest.

LAZAROVICI G. 1979. Neoliticul Banatului. ClujNapoca

1998. Metode şi tehnici moderne de cercetare in arheologie. București.

2000. The eagle - the bird of deadth, regeration resurection and mesenger of the gods. Archaeological and etnological problems. Tibiscum $\mathrm{X} \mathrm{Ca}$ ransebes 2000: 57-68. 
2000a. The eye-symbol, gesture, expression. $T i$ biscum X Caransebeş 2000: 115-122.

2003. Pâinea, grâul și râşnitul sacru în neolitic. Tibiscum XI, 2003: 65-86.

2002-2003. Significations Regarding the Sacral Writing on the Cult Objects from the CarpathianBalkan area. In L. Nikolova (ed.), Early Symbolic System for Communication in Southeast Europe, BAR International Series, 1139, Vol. I: 57-64.

2004a. Simboluri sacre pe obiectele de cult. Semnificații. Festschrift für Florin Medeleț zum 60. Geburstag: 17-59.

2004b. Database for spiritual life, signs and symbols. In Signs of civilisation, International Symposium, May 2004, Novi Sad.

LAZAROVICI G., KALMAR-MAXIM, Z. 1987-1988. Necropolele tumulare din Munţii Petrindului şi Dealul Feleleacului. Acta Musei Napocensis 24-25: 9971009.

\section{Tărtăria. Cluj-Napoca.}

1995. Gura Baciului. Cluj - Napoca BMN, XI.

LAZAROVICI G., DRAŞOVEAN F., MAXIM Z. 2001. Parta. Monografie arheologică, vol. 1 and 2.

LAZAROVICI G., GUMĂ N. 2004. Focul în altărașele de cult, mitologie legată de foc şi de lumină. In VI. Seminar de Etnoreligie „Idei, credinţe, simboluri”, Tema Lumina şi focul sacru, 13-14 noiembrie 2004.

LAZAROVICI G., MIU G. 2004. New Data about Anthropological Analysis from Tărtăria Skeleton Sym. Iashi, ms.

MAKKAY J. 1969. The Late Neolithic Tordos Group of Signs. Alba Regia, X, Székesfehérvár: 9-50.

1990. A Tartariai leletek. Akadémiai Kiadó, Budapest.

MANTU C.-M. 1995. Câteva consideraţii privind cronologia absolută a neo-eneoliticului din România. SCIVA 46, 3-4: 213-235.

1998a. The Absolute Chronology of the Romanian Neolithic and the Neolithic and Aeneolithic/Chalcolithic Periods. The State of the Research. Actes du colloque C14 Archéologie, Lyon: 225- 231. 1998b. Absolute Chronology of Neolithic Cultures in Romania and Relations with the Aegeo - Anatolian World. In M. Otte (ed.) Prehistoire d'Anatolie. Genèse de deux mondes, ERAUL, 85, I: 159174.

2000. Relative and Absolute Chronology of the Romanian Neolithic. Analele Banatului, Serie nouă, Arheologie-Istorie, VII-VIII, 1999-2000: 75-105.

2002. The Absolute Chronology of the Romanian Neolithic and Aeneolithic/Chalcololithic Periods. The State of the research. Dava International, n. 5.

2003. Pre-Writing Signs on Neo-Eneolithic Altars. In L. Nikolova (ed.), Early Symbolic System for Communication in Southeast Europe, BAR International Series, 1139, Oxford, Vol. I: 57-64. on-line http://www.iatp.md/dava/Dava4/mantu_4/ mantu_4.html.

MARCSIK A. 1994. Data to the epidemiology of syphilis in ancient populations in Central Europe. In Dutour 0, Pálfi G., Bérato J, Brun J.-P. (eds.), L'Origine de la syphilis en Europe avant ou apreés 1493? Toulon, Centré Archéol du Var - Éditions Errance: 233-236.

MASSON E. 1984. L'écriture dans les civilisations danubiennes néolithiques. Kadmos, n. 23.

MERLINI M. 2001. Signs, inscriptions, organizing principles and messages of the Balkan-Danube script. In Prehistory Knowledge Project, 2001, on-line http:// www.prehistory.it/scritturaprotoeuropai.htm

2002. On the Origins of Old European Writing. World IFRAO Congress 2002, Skoplje.

2002a. A Neolithic Writing System in Southestern Europe. World IFRAO Congress 2002, Skoplje.

2002b. Inscriptions and messages of the Balkan Danube script. A semiotic approach. on-line www Dava International.

2002c. on-line http://www.iatp.md/dava/Dava6/ Merlini__6_/merlini__6_.html.

2003. Quando la Grande Dea ci insegnò a scrivere. Hera n. 39.

2003a. Scrisuri primordiale din Vechea Europa. on-line www Dava International. 
2003b. on-line http://www.iatp.md/spell.asp?asa $=$ http://www.iatp.md/dava/merlini_8/merlini_8. html.

2003c. Scrierea Dunării: trei sfidări pentru present. Dacia magazine n. 52003.

2003d. Un monumento alla scrittura più antica. Hera n. 45.

2003e. Il codice segreto della grande Tessitrice. Hera n. 45, 2003m

2004. La scrittura è nata in Europa? Avverbi, Roma.

2004a. Challenging some myths on the Tartaria tablets, icons of the Danube script. Novi Sad Symposium. Novi Sad.

MILISAUSKAS S. 2002. European Prehistory. A Survey, Ed. Sarunas Milisauskas. New York, Boston, Dodrecht, London, Moscow.

MILOJČIĆ V. 1965. Die Tontafeln von Tartaria und die absolute Chronologie des mitteleuropaschen Neolithikums. Germania 43: 261-264.

NIKOLOV B. 1986. Singnes sur des ouvrages en ergile de l'epoque préhistorique en Bulgarie occidentale. Studia Praehistorica 8: 166-183.

NIKOLOV B., GEORGIEV G. I. 1970. Débuts d'ecriture du Chalcolithique dans les teres bulgares. Arheologia: 12,3 .

OWENS G. 1999. Balkan Neolithic Scripts. Kadmos Bd. 38.

ORTNER D. and PUTACHAR W. 1985. Identification of Pathological Conditions in Human Skeletal Remains. Smithsonian Institute Press. Washington, D.C.

PAUL I. 1995. Vorgeschichtliche untersuchungen in Siebenburgen. Alba Iulia.

2002. The Mythogram from Ocna Sibiului. on-line http://www.prehistory.it/fase2/paul.htm.

SCHIER W. 2002. Vorschiftliche Zeichenszstem im Neolithikum Südosteuropa (\&.-5. Jt. V. Chr.). Schrift: 24-30.

SCHIER W. \& DRAŞOVEAN F. 2004. Vorberischt über die rumänisch-deutchen Prospektion und Ausgra- bungen in der befestigten Tellsiedlung von Uivar, jud. Timiş, Rumänien (1998-2002). Prehistoriche Zeitschrift 79, 2: 145- 230.

SINN U. (ed.) 2002. Schrift, sprache, Bild Klang. Entwicklungstuffen der Schrift von der antike bis in die Neuzeit, Nachrichten MvWM: 4. Würzburg.

STAROVIĆ A. 2004. Signs of civilisation. Catalogue. Novi Sad.

STUIVER M., REIMER P. J. 1993. Extended 14C database revised Calib. 3.0 14C age calibration program. Radiocarbon 53 (1): 215-230.

TRINGHAM R. 1971. Hunters, Fishers and Farmers of Eastern Europe 6000-3000 B.C. London.

URSULESCU N. 1998. Inceputurile Istoriei pe treitoriul României. Ed. Demiurg, Iaşi.

2004. Nouvelles données concernant les croyances magiques des communautes de la civilisation Précucuteni (énéolithique ancien) de l'est de la Roumanie. Actes du XIV-emme Congrès UISPP, section 9-10: 323-348.

URSULESCU N., BOGHIAN D., COTIUGA V. 1999. Târgu Frumos-Baza Pătule. Cronica cercetărilor arheologice din România, Vaslui: 120-121.

URSULESCU N., COTIUGA V., BOGHIAN D., ISTINA L., HAIMOVICI S., COROLIUC A. 2001. Târgu Frumos, jud. Iaşi, Baza Pătule. Cronica cercetărilor arheologice din România. Campania 2000: 252-254.

URSULESCU N., MERLAN V., TENCARIU F. 2002. Isaiia, com. Răducăneni, jud. Iaşi, Balta Popii. Cronica cercetărilor arheologice din România. Campania 2001: 161.

VLASSA N. 1962. Probleme ale cronologiei neoliticului Transilvaniei în lumina stratigrafiei aşezării de la Tărtăria. Studia Universitatis Babeș-Bolyai, Series Historia, fasciculus 2: 23-30.

1962a. Atti del VI Congresso Internationale delle Scienye Preistoriche e Protoistoriche, II, Roma: 267-268.

1964. Chronology of the Neolithic in Transylvania in the Light of the Tărtăria Settlements Stratigraphy. Dacia VII. 
1965. In Atti del VI Congresso Internazionale delle Scienze Preistoriche e Protostoriche, vol. II, Roma: 267-269.

1970. Kulturelle Beziehungen des Neolithikums Siebenburgens zum Vorderen Orient. Acta Musei Napocensis VII: 3-39.

1971. Contribuţii la Problema racordării cronologiei relative a neoliticului Transilvaniei la cronologia Orientului Opropiat. Apulum IX: 21-63.

1976. Neoliticul Transilvaniei. BMN 3: 161-197.

WINN SHAN M. 1981. Pre-writing in Southeastern Europe: The Sign System of the Vinča Culture ca. 4,000 BC. Western Publishers. Calgary: 185.
2003. The Old European Script. Further evidence, Economic and religious stimuli. online: Prehistory Knowledge, Virtual museum of the Inscriptions, The Global Prehistory Consortium at Euro Innovanet.

2004. From Vinča Script and academic scepticism to Danube Script and the ritual use of sings. Symp Signs of civilisation.

ZANOTTI D. G. 1983. The position of the Tărtăria tablets within the Southeast European Copper Age. American Journal of Archaeology 87 (2): 209-213. 